\title{
Pengaruh Manajemen Kepemimpinan Kepala Sekolah dan Motivasi terhadap Kinerja Guru (Studi pada Madrasah Aliyah Negeri 1 Kota Makassar)
}

\author{
Surani $^{\mathrm{a}, 1}$, Nashiruddin Pilo ${ }^{\mathrm{a}, 2}$ \\ aDosen Tetap Universitas Muslim Indonesia \\ 1'surani@umi.ac.id; ${ }^{2}$ naspil58@gmail.com
}

\begin{abstract}
Abstrak
Pemimpin memiliki pengaruh positif terhadap nilai-nilai dalam organisasi seperti motivasi dan kinerja anggota kelompok. Oleh karena itu apabila kepemimpinan kepala madrasah rendah, maka akan berdampak pada rendahnya tingkat kinerja seorang guru, yang mana ada guru yang kinerjanya kurang memuaskan, tidak berprestasi, yang merasa tidak dihargai atas apa yang telah dikerjakan, tidak puas dengan pekerjaan yang telah dikerjakan dan dikerjakan. tidak berani mengambil resiko, kondisi ini menunjukkan adanya rasa tidak puas dalam kinerja bagi seorang guru. Keberhasilan suatu lembaga pendidikan sangat ditentukan oleh peran pemimpinnya, karena kepala madrasah sebagai pimpinan dalam lembaga harus mampu memimpin lembaga tersebut menuju pencapaian tujuan yang telah ditetapkan. Kepala madrasah harus mampu melihat perubahan norma pendidikan dan kehidupan globalisasi. Dengan demikian kepala Madrasah saat ini mensyaratkan bahwa pengetahuan dan keterampilan untuk memimpin secara efektif baik dari sisi biaya maupun wewenang. Oleh karena itu, jika pimpinan madrasah tidak paham, maka tidak semuanya akan terjadi. "Agar terjadi" hari ini, kepala Madrasah harus memainkan peran visioner, agen perubahan, panutan, dan manajer.
\end{abstract}

Kata Kunci: Manajemen, Kepemimpinan, Motivasi, Kinerja

\section{Pendahuluan}

\subsection{Latar Belakang Masalah}

'Kepemimpinan merupakan aspek yang harus diperhatikan dalam suatu organisasi. Menurut Veithzal Zainal Rivai dan Arviyan Arifin (2009:113) dikatakan bahwa ada empat sifat yang harus dipenuhi sabagai seorang pemimpin, yani; pertama: Shiddiq yaitu kejujuran, kesungguhan dan kebenaran dalam bersikap dan selalu berlandaskan ucapan, keyakinan serta perbuatan berdasarkan nilai-nilai ajaran Islam, kedua: Tabligh yaitu penyampaian yang jujur dan bertanggung jawab, keterbukaan sekaligus memberikan contoh kepada pihak lain untuk melaksanakan ketentuanketentuan ajaran Islam dalam kehidupan sehari-hari, ketiga: Amanah yaitu kepercayaan yang diberikan baik dari Allah SWT maupun dari orang-orang yang dipimpin harus dijaga dengan baik, keempat: Fathanah yaitu kecerdasan dalam memahami secara mendalam segala hal yang menjadi tugas dan kewajiban. Sifat ini dapat menimbulakan kreatifitas seorang tenaga pendidik (guru) untuk dapat berinovasi dalam menjalankan tugas dan tanggungjawabnya, sehingga kreativitas akan muncul ketiga guru selalu mengembangkan dan meningkatkan kompetensi yang berujung pada pencapaian kinerjanya, maka seorang pemimpin (Kepala Sekolah) harus memahami tentang konsep kepemimpinan dengan baik.

Kepala madrasah yang mampu menjalankan fungsinya akan mampu mengimplementasikan visinya menjadi aksi dalam paradigma baru manajemen pendidikan Islam. Seorang pemimpin harus memiliki strategi atau inovasi yang berkaitan dengan kepemimpinannya, terutama memiliki kapasitas kepemimpinan untuk perbaikan berkelanjutan, yang berkomitmen pada tugas dan tujuan organisasi. Karena dalam organisasi yang dinamis mengandung sekelompok orang untuk mencapai kesamaan visi, maka lingkungan yang mendukung kegiatan kepemimpinan untuk dapat menciptakan iklim kerjasama yang sinergis antar subsistem organisasi sehingga anggota organisasi mempunyai komitmen. , integritas dan tanggung jawab kolektif untuk keseluruhan kinerja organisasi.

Pemimpin yang bekerja dalam kelompok tentunya memberikan nilai tambah bagi pengikutnya bagi organisasi, selalu menghadirkan solusi kreatif dalam hidup, sehingga pemimpin berdampak 
positif terhadap nilai-nilai organisasi seperti motivasi, kepuasan dan kinerja serta rasa. keamanan bagi anggota. grup.

Oleh karena itu apabila kepemimpinan kepala sekolah yang rendah akan berdampak pada rendahnya tingkat prestasi seorang guru, dimana ada guru yang kinerjanya kurang memuaskan, tidak tercapai, merasa tidak dihargai atas apa yang telah dikerjakan, tidak puas dengan pekerjaan yang telah dilakukannya dan tidak berani mengambil resiko, kondisi ini menunjukkan adanya rasa ketidakpuasan terhadap seorang guru.

Penyelenggaraan pendidikan yang bermutu sangat erat kaitannya dengan keberhasilan peningkatan kompetensi dan profesionalisme tenaga pendidik dan tenaga kependidikan (PTK) tanpa mengabaikan faktor lain seperti sarana, prasarana dan pendanaan. Kepala madrasah merupakan salah satu PTK yang posisinya sangat signifikan dan strategis dalam meningkatkan profesionalisme guru dan mutu pendidikan di madrasah.

Peran kepemimpinan kepala madrasahlah yang sangat menentukan keberhasilan sebuah lembaga pendidikan Islam. Karena kepala madrasah adalah ketua lembaga, maka pimpinan madrasah harus mampu membimbing lembaga tersebut menuju pencapaian tujuan yang telah ditetapkan. Kepala madrasah harus mampu melihat perubahan norma pendidikan dan dalam dunia globalisasi.

Pimpinan kepala sekolah madrasah sangat mendukung tercapainya pengelolaan madrasah yang efektif dan efisien. Untuk mewujudkan madrasah yang efektif dan efisien, kepala madrasah sebagai pengelola pendidikan setingkat sekolah dan terdepan dalam pengelolaan pendidikan harus mampu melaksanakan tugas dan bertanggung jawab untuk berperan aktif dalam pemajuan Lembaga Pendidikan Islam.

Berkaitan dengan latar belakang tersebut, fenomena yang mendasari penelitian ini adalah belum optimalnya pengaruh manajemen kepemimpinan dan motivasi utama terhadap peningkatan kinerja guru. Dengan demikian, sebagai kepala madrasah dibutuhkan pengetahuan dan keterampilan untuk memimpin secara efektif baik dari segi biaya maupun kewenangan. Untuk alasan ini, menurut Profesor Lowa State Education Administrator dan penulis blog Dangerously Irrelevant, Scott McLeod berkata, "jika pemimpin sekolah tidak mengerti, itu tidak akan terjadi". "Untuk terjadi" hari ini, kepala sekolah harus memiliki peran visioner, agen perubahan, panutan, dan manajer.

\subsection{Permasalahan}

a. Apakah Manajemen Kepemimpinan Kepala Madrasah berpengaruh terhadap Kinerja Guru pada MAN 1 Kota Makassar?

b. Apakah Motivasi Kepala Madrasah berpengaruh terhadap Kinerja Guru pada MAN 1 Kota Makassar?

\section{Tinjauan Pustaka}

\subsection{Landasan Teori}

Dalam istilah manajemen, bahasa tersebut berasal dari bahasa Inggris yang merupakan terjemahan langsung dari kata manajemen yang artinya manajemen, administrasi atau manajemen. Sedangkan (Mochtar Efendy: 1986) mengemukakan bahwa manajemen berasal dari kata kerja bahasa Inggris "To Manage" yang identik dengan to hand, to control, and guide (take care, check and lead), sehingga manajemen dapat diartikan sebagai mengelola, mengendalikan, melakukan atau membimbing.

Sedangkan (Ramayulis: 2008) dalam bukunya, Ilmu Pendidikan Islam, menyatakan bahwa pengertian yang sama dengan hakikat manajemen adalah al-tadbir (pengaturan), kata ini merupakan persamaan dari kata dabbara (mengatur) seperti yang terdapat dalam Q.S. As-Sajadah (32): 5

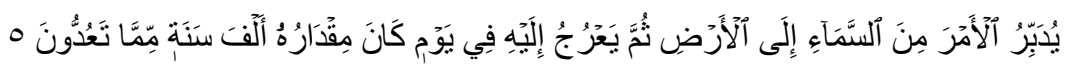


Terjemahnya :

Dia mengatur urusan dari langit ke bumi, kemudian (urusan) itu naik kepada-Nya dalam satu hari yang kadarnya adalah seribu tahun menurut perhitunganmu.

Isi ayat tersebut terlihat bahwa Allah swt adalah pengelola alam (pengelola), alam semesta merupakan bukti kebesaran Allah SWT dalam mengelola alam semesta ini. Namun karena manusia ciptaan Allah SWT dijadikan khalifah di muka bumi, maka ia harus mengatur dan mengelola bumi dengan sebaik-baiknya sebagaimana Allah yang mengatur alam semesta ini, sehingga pengelolaan yang sesuai dengan istilah tersebut dapat dikatakan. menjadi proses mengkoordinasikan kegiatan kerja agar dapat diselesaikan. efisien dan efektif dengan dan melalui orang lain. Berdasarkan definisi sumber daya manusia yang berbeda, manajemen dapat diartikan sebagai proses yang menggunakan sumber daya manusia dan sumber daya lainnya untuk mencapai suatu tujuan.

Kepemimpinan, Menurut Rasyid (2000:95) kepemimpinan adalah sebuah konsep yang merangkum berbagai segi dari interaksi pengaruh antara pemimpin dan pengikut dalam mengejar tujuan bersama. Kepemimipinan seorang leader, di manapun itu, akan memberikan pengaruh kepada kinerja organisasi tersebut. Namun, pengaruh baik atau buruk bagi organisasi bergantung pada gaya kepemimpinan yang diterapkan oleh sang pemimpin. Riset terkemuka mengenai pengaruh pemimpin dan gaya kepemimpinannya dipaparkan oleh Daniel Goleman (2000), seorang peneliti dan Psikolog dari Harvard University, yang menciptakan Teori Kepemimpinan Primal (Primal Leadership Theory), dimana seorang pemimpin paling harus memiliki kecerdasan emosional.

Berkat kecerdasan emosinya, ia mampu berinteraksi dengan lingkungan dimanapun ia berada. Pengendalian emosi sangat penting dalam kehidupan manusia karena melalui pengendalian emosi sangat jarang terjadi bentrok di antara mereka. Jika seseorang mampu mengenali, mengendalikan emosinya, dan dapat menyalurkan emosi tersebut ke arah yang benar dan bermanfaat, maka ia akan cerdas secara emosional. Dengan menggunakan aspek kecerdasan emosi secara benar, otomatis sikap yang diharapkan akan muncul. Perkembangan kecerdasan emosional sangat erat kaitannya dengan kepemimpinan dan pengembangan kepribadian serta kematangan kepribadian sebagai pemimpin.

Terry (2016:79) mengungkapkan ada 6 (enam) tipe kepemimpinan dalam organisasi, yaitu:

a. Kepemimpinan pribadi (personal leadership) suatu tipe di mana pemimpin secara langsung menghubungi/mengadakan kontak dengan bawahannya. Mereka tidak melihat adanya jenjangjenjang hierarki, yang berarti sudah ada delegasi wewenang dan tanggung jawab.

b. Kepemimpinan non pribadi (non personal leadership), pemimpin tidak langsung mengadakan kontak dengan bawahannya, melainkan melalui sistem jenjang hierarki (Subordinasi)

c. Kepemimpinan demokratis (democratic leadership), pemimpin selalu membuka pintu dan menghargai saran, pendapat, dan nesihat dari para kolega, melalui forum musyawarah untuk mufakat guna mencapai kata sepakat.

d. Kepemimpinan Otoriter (Autoritarian Leadership) suatu tipe dimana pemimpin menganggap, bahwa kepemimpinan merupakan hak pribadinya, tak boleh ada orang yang turut campur sehingga tiap perintah dan instruksi tidak perlu mendapat konsultasi dari kolega-koleganya.

e. Kepemimpinan Paternalistik (Paternalistic Leadership) memiliki ciri pemimpin bertindak sebagai ayah, pembimbing, pelindung bagi bawahannya.

f. Kepemimpinan menurut Bakat (Indogenious Leadership) kepemimpinan yang timbul dari kelompok-kelompok organisasi informal yang melahirkan bidang keahlian dimana ikut berkecimpung pada organisasi tersebut.

Kepemimpinan dalam terminology Islam dalam beberapa term yang berkaitan dengan pemimpin atau manager, yakni imam, khalifah, wali, ulil amri, rain dan malik. Istilah tersebut dimana konsep utamanya berkaitan dengan mengatur orang atau barang supaya dapat digunakan untuk mencapai tujuan organisasi. Selanjutnya dalam Al-qur'an istilah kepemimpinan diungkapkan dengan istilah khalifah. Hal ini terdapat dalam Q.S. Al-Baqarah (2): 30.

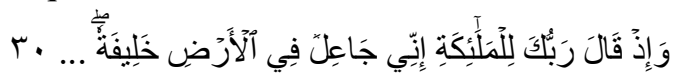


Terjemahnya:

"Ingatlah ketika Tuhanmu berfirman kepada para malaikat, sesungguhnya Aku hendak menjadikan seorang khalifah di muka bumi."

Posisi informal khalifah tidak dapat dipisahkan. Kata-kata khalifah dalam ayat tersebut ditujukan tidak hanya kepada khalifah setelah Nabi, tetapi juga kepada penciptaan Nabi Adam (as), yang disebut sebagai manusia yang tugasnya adalah membuat kemakmuran di bumi, termasuk mengajak orang lain untuk melakukannya. ma'ruf dan diimbangi dengan mencegah perbuatan jahat.

Motivasi berasal dari kata "movere" yang berarti "dorongan atau daya penggerak". Menurut Rivai (2018:665), istilah motivasi secara harfiah diartikan sebagai "dorongan" yang timbul pada diri seseorang secara sadar atau tidak sadar untuk melakukan tindakan sesuai tujuan tertentu. Istilah motivasi juga sering diartikan sebagai daya gerak, penyebab seseorang untuk melakukan berbagai aktivitas dengan tujuan tertentu.

Ada lima teori motivasi yang mendukung, yaitu teori hirarki kebutuhan dari Maslow, teori $\mathrm{X}$ dan Y dari McGregor, teori prestasi McClelland, teori harapan dari Vroom dan teori ERG dari Clayton Alderfer. Teori yang menjadi pengamatan utama yang digunakan pada penelitian ini mengacu pada teori ERG.

Robbins (2016:214-215) menyatakan bahwa secara hirarki dan kronologis menurut Maslow, setiap manusia termotivasi untuk memenuhi kebutuhan utama, yaitu kebutuhan fisiologis. Setelah kebutuhan ini terpenuhi atau terpuaskan, barulah menginjak pada kebutuhan kedua (lebih tinggi) yaitu kebutuhan akan keamanan. Kebutuhan ketiga baru dilaksanakan setelah kebutuhan kedua terpenuhi. Proses seperti ini berjalan terus sampai akhirnya terpenuhi kebutuhan kelima (aktualisasi diri).

Proses tersebut menunjukkan bahwa kebutuhan-kebutuhan itu saling tergantung dan saling menopang seseorang untuk termotivasi, hal ini sesuai dengan hirarki kebutuhan Maslow, yang dapat diliat pada gambar sebagai berikut:

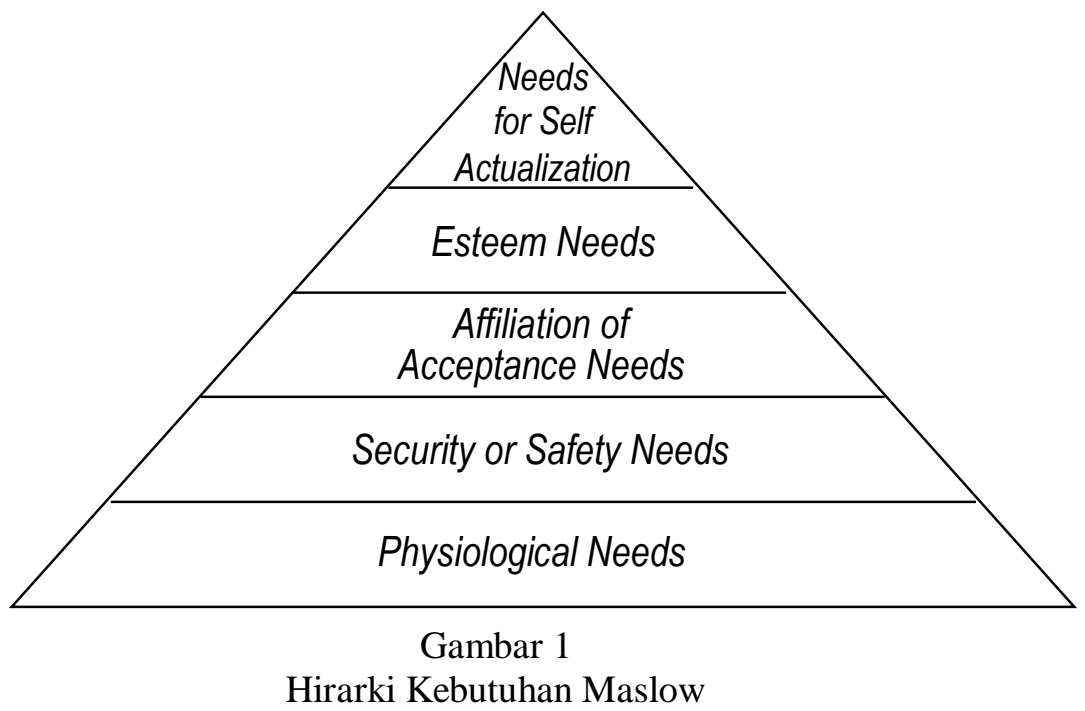

Sumber: Robbins (2006:152)

Berikut interprestasikan mengenai hirarki kebutuhan motivasi Maslow:

a. Physiological needs (kebutuhan fisiologis) merupakan kebutuhan yang paling mendasar dari setiap manusia karena berkaitan dengan kebutuhan dasar yaitu kebutuhan seperti rasa lapar, haus, seks, rumah, tidur dan sebagainya.

b. Safety or security needs (kebutuhan keamanan atau perlindungan) adalah tingkat kedua dari hierarki kebutuhan. Dalam hal ini Maslow menekankan baik emosional maupun fisik, sehingga 
demonstrasi berupa tuntutan keselamatan, perlindungan dari bahaya, ancaman, dan perampasan atau pemecatan dari pekerjaan.

c. Love needs (kebutuhan cinta) adalah kebutuhan tingkat ketiga yang berhubungan dengan kebutuhan kasih sayang atau afiliasi atau kebutuhan sosial (Luthans, 2017: 200). Sedangkan Koontz et al., (2016: 153) mengartikannya sebagai afiliasi dengan kebutuhan penerimaan, yaitu kebutuhan akan cinta dan motivasi dalam membangun hubungan dengan orang lain. Motivasi dan perasaan membangun dan diterima dalam kelompok, rasa kekeluargaan, persahabatan dan kasih sayang.

d. Esteem needs (kebutuhan akan penghargaan) menggambarkan kebutuhan seseorang uang tingkat tinggi yaitu kebutuhan akan status atau jabatan, harga diri, reputasi dan motivasi.

e. Needs for self actualization (kebutuhan akan aktualisasi diri) adalah puncak dari semua tingkatan kebutuhan manusia, yaitu kebutuhan akan realisasi diri untuk menggunakan pengembangan diri secara maksimal, kreatifitas, ekspresi diri dan melakukan apa yang paling sesuai, serta ketuntasan. pekerjaan seseorang.

Oleh karena itu, motivasi sangat penting untuk meningkatkan kinerja, karena efektivitas bergantung pada pemutakhiran hasil yang dicapai. Cusnanto (2017: 223) menyatakan bahwa motivasi keinginan dalam diri seseorang memacu dirinya untuk melakukan sesuatu yang menjadi dasar atau alasan mengapa seseorang berperilaku. Motivasi dapat diartikan sebagai harapan yang memotivasi seseorang untuk bekerja.

Produktivitas, menurut Smith dari Sedarmayanti, menyatakan bahwa produktivitas adalah "titik awal proses, orang atau orherwiss". Jadi dapat dikatakan efisiensi merupakan hasil atau hasil dari suatu proses, sehingga kinerja mencerminkan keberhasilan suatu pekerjaan.

Bagi guru, peningkatan kinerja penting untuk menunjukkan prestasi kerja dalam suatu organisasi. Kinerja adalah konsep universal untuk realisasi tujuan organisasi. Bagi seorang guru yang berprestasi, perlu mengevaluasi keberadaannya dalam organisasi yang mampu menjalankan tugasnya berdasarkan hasil yang ingin dicapai. Dessler (2018: 49) mengemukakan teori evaluasi kinerja (performance evaluation) yang menurutnya kinerja adalah pekerjaan yang dilakukan oleh seseorang atau kelompok dalam suatu organisasi, sesuai dengan kewenangan dan tanggung jawabnya masingmasing untuk mencapai tujuan. dari organisasi yang terpengaruh secara hukum. tidak melanggar hukum, yang sesuai secara moral atau etika.

Prestasi kerja ini merupakan perwujudan dari kinerja seorang guru. Prestasi atau hasil merupakan hasil akhir dari apa yang dilakukan guru untuk mencapai suatu tujuan. Pencapaian hasil kerja juga merupakan bentuk membandingkan pekerjaan seseorang dengan standar yang telah ditetapkan, apabila pekerjaan seseorang sesuai dengan standar kerja atau bahkan melebihi standar maka dapat dikatakan kinerjanya semakin baik, sehingga evaluasi kinerja guru juga dievaluasi berdasarkan teori reputasi di tempat kerja oleh Marchel (2018: 85). Teori ini berarti bahwa siapa pun yang mampu menunjukkan reputasi kerja berarti telah mencapai hasil berdasarkan peningkatan kinerja yang telah mereka capai. Ini relevan dengan upaya yang ditunjukkan oleh para guru yang berusaha membuktikan reputasi mereka untuk pekerjaannya dalam proses belajar mengajar.

Kinerja guru memiliki spesifikasi tertentu. Kinerja guru dapat dilihat dan diukur berdasarkan kekhususan atau kriteria kompetensi yang harus dipenuhi oleh setiap guru. Dilihat dari kinerja guru, jenis perilaku yang terlibat adalah aktivitas guru dalam proses pembelajaran. Mengenai teori standar kinerja guru, Sahaham (2018: 49) menyatakan bahwa standar kinerja guru berkaitan dengan kualitas guru dalam melaksanakan tugasnya seperti: (1) kemampuan merencanakan dan mempersiapkan pengajaran, (2) ) penguasaan materi yang akan diajarkan kepada siswa, (3) penguasaan metode dan strategi pengajaran, (4) penugasan tugas kepada siswa, (5) kemampuan mengelola siswa, dan (6) kemampuan melakukan evaluasi dan membuat evaluasi.

Oleh karena itu dalam pandangan Islam, pekerjaan yang dilakukan dengan penuh kesungguhan memberikan pencapaian kinerja yang maksimal yang Allah balas dengan pahala yang lebih baik dari apa yang dikerjakan. Kinerja merupakan kunci dari segala urusan untuk berbuat amal saleh, karena 
itu Allah tidak menyia-nyiakan segala pekerjaan yang didasari dengan amalan saleh, hal ini Allah tegaskan dalam Q.S. Al Kahf $(18: 30)$,

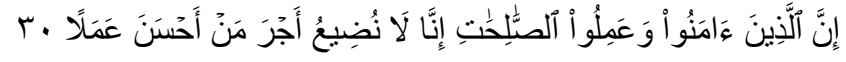

Terjemahnya:

Sesunggunya mereka yang beriman dan beramal saleh, tentulah Kami tidak akan menyia-nyiakan pahala orang-orang yang mengerjakan amalan(nya) dengan yang baik.

Ayat ini memerintahkan kepada orang beriman dan beramal saleh untuk terus mengerjakan amal yang lebih baik sesuai dengan kinerjanya. Kinerja memiliki posisi penting dalam manajemen dan organisasi, karena keberhasilan dalam melakukan pekerjaan sangat ditentukan oleh kinerja (Uni dan Lamatenggo, 2016:118).

\section{Pembahasan}

\subsection{Kepemimpinan terhadap Kinerja Guru}

Hasil penelitian membuktikan bahwa kepemimpinan kepala madrasah berpengaruh positif dan signifikan terhadap kinerja guru MAN 1 Kota Makassar. Hal ini dapat diinterpretasikan bahwa kepemimpinan kepala madrasah yang diterapkan selama ini telah berorientasi dengan hasil yang dapat meningkatkan kinerja guru. Terlihat kepemimpinan berdasarkan pribadi, non pribadi, demokratis, otoriter, paternalistik dan bakat yang dimiliki oleh kepala madrasah memberikan kontribusi terhadap peningkatan kinerja guru dalam menerapkan standar kinerja proses belajar mengajar yang diharapkan, utamanya dalam peningkatan kemampuan guru membuat perencanaan dan persiapan, penguasaan materi, metode mengajar, pemberian tugas, pengelolaan siswa, penilaian dan evaluasi belajar yang telah dicapai sampai saat ini. Intinya kepemimpinan kepala madrasah memiliki kontribusi dalam meningkatkan kinerja guru.

Fakta yang ditemukan di MAN menunjukkan bahwa, kepemimpinan kepala madrasah berpengaruh positif terhadap kinerja guru kenyataannya terlihat bahwa kepala madrasah di dalam mengarahkan guru berfokus pada orientasi peningkatan prestasi belajar atau pencapaian hasil proses belajar mengajar. Selama ini guru merasa bahwa keberadaan kepala madrasah telah mengarahkan para guru untuk memperhatikan dan meningkatkan kinerjanya secara mandiri dalam membuat perencanaan dan persiapan mengajar, penguasaan materi, penyampaian metode mengajar, pemberian tugas, pengelolaan siswa, penilaian dan evaluasi.

Memahami hal tersebut di atas, maka perlu diuraikan per indikator variabel kepemimpinan dari kepala madrasah yang posistif dan signifikan terhadap kinerja guru. Pertama, indikator kepemimpinan pribadi dari kepala madrasah selama ini memberikan perhatian kepada individu guru yang berorientasi pada penilaian hasil kerja guru dalam proses belajar mengajar.

Kedua, kepemimpinan yang bersifat non pribadi ditunjukkan kepala madrasah dalam pendelegasian tanggungjawab selama ini berpengaruh positif terhadap kinerja guru. Ini dikarenakan kepala madrasah di dalam menerapkan kepemimpinan non pribadi berorientasi kepada pencapaian prestasi hasil kerja guru dengan mempertimbangkan aspek kompetensi dan prestasi guru yang layak untuk didelegasikan atau diwewenangkan menjalankan tugas belajar mengajar dengan baik, dengan demikian para guru melalui kepemimpinan non pribadi yang diterapkan memberikan pengaruh terhadap peningkatan kinerja guru.

Ketiga, kepemimpinan demokratis yang diterapkan selama ini oleh kepala madrasah dalam melakukan dengar pendapat atau masukan dari guru ternyata berkontribusi positif dan signifikan terhadap kinerja guru. Alasannya karena kepala madrasah selama ini mengajak setiap guru untuk berdiskusi, berkomunikasi dan rapat dalam setiap pengambilan keputusan yang dilakukan berdasarkan hasil keputusan bersama, sehingga keputusan yang diambil selalu berorientasi pada pencapaian hasil kerja atau kinerja guru.

Keempat, kepemimpinan otoriter bagi kepala madrasah biasa ditunjukkan dengan kebiasaan pimpinan memberikan perintah atau instruksi yang harus dilaksanakan dengan cepat dan ini biasanya 
ditunjukkan dengan kebiasaan kepala madrasah yang tegas kepada guru untuk melaksanakan perintahnya, sehingga guru dengan cepat pula memberikan respon atas perintah kepala madrasah, di mana kepala madrasah jarang memberikan perintah untuk meningkatkan kinerja guru secara tegas, sehingga guru hanya patuh dan taat pada perintah yang diberikan oleh pimpinan yang sifatnya tuntutan keinginan dan kebutuhan pimpinan saja, tidak berorientasi pada perbaikan atau peningkatan hasil proses belajar mengajar guru di MAN. atau dengan kata lain guru hanya fokus memperhatikan dan melayani tuntutan kepentingan perintah atau instruksi pimpinan yang menyebabkan guru kurang meningkatkan dan mengembangkan pencapaian hasil kerjanya secara maksimal yang menyebabkan kinerja mengajar rendah bahkan menurun.

Kelima, kepemimpinan paternalistik yang ditunjukkan oleh kepala madrasah bersifat kebapakan yang selalu membimbing, menasehati dan mengayomi guru tanpa mengarahkan atau mempengaruhi guru untuk selalu meningkatkan kinerjanya dalam proses belajar mengajar. Akibatnya guru kurang memiliki inovasi dan kreativitas untuk mengembangkan dan meningkatkan kinerjanya, sebab guru merasa kepala madrasah dapat melindungi bahkan hanya menasehati guru apabila tidak dapat meningkatkan hasil kerjanya. Karena itu, di satu sisi guru membutuhkan andil kepala madrasah sebagai pelindung dalam bekerja, tetapi di satu sisi ini menjadi penyebab guru kurang mampu mengembangkan eksistensinya dalam meningkatkan kinerjanya.

Keenam, kepemimpinan talenta/bakat dari kepala madrasah senantiasa menunjukkan keahlian yang dimilikinya untuk memimpin para guru di dalam menjalankan pekerjaannya pada proses belajar mengajar di madrasah, sehinggga bakat memimpin yang dimiliki kepala madrasah dapat meningkatkan kinerja guru pada proses belajar mengajar di MAN.

Uraian per indikator di atas dapat disimpulkan bahwa kepemimpinan dari kepala madrasah baik berupa pribadi, non pribadi, demokratis, otoriter, paternalistik dan bakat cenderung bersifat kepemimpinan yang subjektif dari kepala madrasah, di mana kepemimpinan tersebut mengarahkan, menggerakkan dan mempengaruhi guru untuk meningkatkan kinerjanya. Kepemimpinan yang dimiliki kepala madrasah berorientasi pada kepentingan, kebutuhan dan tuntutan kepala madrasah kepada bawahannya yang dipimpinnya untuk dapat meningkatkan kinerjanya. Karena itu kepemimpinan yang diemban kepala madrasah berpengaruh posistif terhadap kinerja guru, dan signifikan (nyata) keberadaan kepemimpinan kepala madrasah dibutuhkan dalam meningkatkan kinerja guru, itulah sebabnya kepemimpinan harus berorientasi kepada peningkatan kinerja guru.

Mengingat pentingnya kepempinan terhadap kinerja guru, maka perlu ada upaya untuk terus meningkatkan kepemimpinan yang memberikan pengaruh positif dan signifikan terhadap kinerja guru. Karenanya perlu penerapan konsep manajemen pendidikan Islam yang mendorong setiap pimpinan untuk selalu memperbaiki dan meningkatkan kepemimpinannya dalam meningkatkan kinerja, seperti dalam Al-Quran dan Hadits Nabi, kepemimpinan sangat penting bagi setiap manusia, seperti dalam Q.S. As Sajdah (32:24),

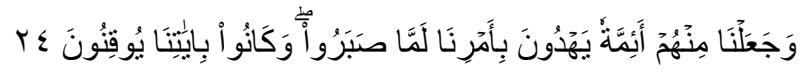

Terjemahnya:

Dan Kami jadikan di antara mereka itu pemimpin-pemimpin yang memberi petunjuk dengan perintah Kami ketika mereka sabar. Dan adalah mereka meyakini ayat-ayat Kami.

Ayat Al-Quran diatas memberikan penegasan bahwa dalam kehidupan manusia dibutuhkan keberadaan pemimpin, karena itu Allah SWT menjadikan diantara manusia ada pemimpin yang mampu mewujudkan kepemimpinan yang dapat memberikan petunjuk dengan perintah yang tujuannya untuk bersabar dalam mewujudkan tujuannya. Ini berarti, keberadaan kepala madrasah menjadi penting sebagai seorang pemimpin yang memimpin para guru sebagai bawahannya dengan memberikan petunjuk sesuai dengan tipe kepemimpinannya dengan selalu memperbaiki kepemimpinannya baik berupa kepemimpinan pribadi, non pribadi, demokratis, otoriter, paternalistik dan bakat yang dimiliki kepala madrasah untuk mengarahkan, menggerakkan dan mempengaruhi bawahannya untuk terus meningkatkan kinerjanya. Pemimpin ini harus memiliki kesabaran di dalam 
memimpin para guru untuk mengembangkan segala potensi dan eksistensinya untuk memperoleh hasil kerja dalam proses belajar mengajar yang maksimal untuk meningkatkan kinerjanya.

Konteks ayat ini juga relevan dengan Hadits Nabi Muhammad SAW yang memerintahkan untuk bersabar menghadapi pemimpin dengan sabdanya: "Barangsiapa mendapati sesuatu yang tidak dia sukai pada pemimpinnya, hendaklah ia bersabar". Hadits ini dapat diinterpretasikan bahwa apabila kepala madrasah sebagai seorang pemimpin tidak disukai karena tidak mampu mengarahkan dan mempengaruhi bawahan untuk meningkatkan kinerjanya, maka seharusnya guru harus bersabar dalam menghadapi kepemimpinan kepala madrasah tersebut. Karena sesungguhnya menurut Umar bin Khattab ra berkata "Islam tidak akan tegak kecuali dengan jamaah, dan jamaah tidak akan tegak kecuali dengan pemimpin, sedangkan pemimpin tidak akan tegak kecuali dengan ketaatan kepadaNya". Perkataan Umar ra ini menjadi pertimbangan bagi seorang pemimpin untuk memperbaiki kepemimpinannya dengan sebaik-baiknya dalam suatu jamaah atau dalam hal ini organisasi madrasah dengan memperbaiki ketaatan bawahan kepada pemimpinnya dengan mengarahkan para guru untuk meningkatkan kinerjanya.

Ayat Al-Quran dan Hadits di atas, juga didukung oleh teori yang relevan yaitu teori model Fiedler dalam Wilson (2017:347) kepemimpinan yang efektif bergantung pada penyesuaian yang tepat antara kepemimpinan dalam berinteraksi dengan bawahan untuk menyesuaikan situasi tertentu yang memberikan kendali dan pengaruh kepemimpinan itu. Maksudnya, seorang pemimpin tidak hanya memahami dirinya tetapi harus memahami tuntutan kondisional yang dinginkan oleh bawahan dalam hal ini guru untuk meningkatkan kinerjanya. Implikasi dari teori ini menegaskan bahwa keberhasilan guru dalam meningkatkan kinerjanya merupakan aktualisasi bahwa keberhasilan guru adalah keberhasilan pemimpin.

\subsection{Motivasi terhadap Kinerja Guru}

Hasil penelitian membuktikan bahwa motivasi berpengaruh positif dan signifikan terhadap kinerja guru MAN 1 Kota Makassar. Hal ini dapat diinterpretasikan bahwa motivasi yang dirasakan guru sudah sesuai dengan kebutuhannya. Akibat motivasi yang terpenuhi, maka pencapaian kinerja guru MAN 1 dapat meningkat. Penyebab motivasi guru yang terpenuhi akan kebutuhan psikologis, rasa aman, sosial, penghargaan dan aktualisasi diri yang sesuai dengan tuntutan kebutuhannya, akibatnya motivasi berpengaruh positif dan signifikan di dalam meningkatkan kinerja guru sesuai dengan aktivitas proses belajar mengajar yang diembannya.

Fakta yang menunjukkan bahwa motivasi kerja guru terpenuhi sesuai kebutuhannya, secara psikologis gaji guru yang diterima cukup untuk dapat memenuhi kehidupan yang lebih layak, guru merasa aman atas penggunaan alat dan perlengkapan mengajar, merasakan ketenangan sosial dengan sejawatnya, mendapatkan penghargaan atas dedikasi kerja yang telah dicapai dan diberikan peluang untuk mengaktualisasikan dirinya dalam berbagai kreativitas kerja dan prestasi. Fakta inilah yang menyebabkan motivasi kerja guru berpengaruh posistif dan signifikan terhadap peningkatan kinerja guru dalam membuat perencanan/persiapan mengajar, penyajian materi, penguasaan metode, pemilihan tugas, pengelolaan siswa serta penilaian dan evaluasi atas pekerjaan yang dilakukan dalam proses belajar mengajar di MAN 1.

Fakta tersebut dapat dijelaskan dalam per indikator dari motivasi kerja yang berpengaruh positif dan signifikan terhadap kinerja guru. Pertama, indikator fisiologis dari motivasi dikatakan berpengaruh positif dan signifikan, karena selama ini guru sebagai manusia biasa yang mempunyai keluarga memiliki banyak tuntutan hidup yang harus dipenuhi, untuk memenuhi hal tersebut dengan gaji guru MAN saat ini dianggap cukup dalam pemenuhan kebutuhan fisiologisnya sehinga hal ini juga dapat meningkatkan kinerjanya dalam menjalankan tugasnya sebagai guru. Inilah yang menjadi alasan guru termotivasi dalam menjalankan tugas kerjanya dan aktivitas proses belajar mengajar yang dilakukan oleh guru dan ini berdampak pada pencapaian hasil kerja sesuai dengan target kinerja yang diharapkan. Intinya, motivasi kerja guru dalam bentuk pemenuhan kebutuhan fisiologis yang cukup akan berpengaruh positif dan signifikan dalam meningkatkan kinerja guru MAN. 
Kedua, indikator rasa aman dari motivasi yang dimiliki guru selama ini dirasakan berpengaruh positif dan signifikan terhadap pencapaian kinerja guru. Inilah salah satu yang menjadi pemikiran guru selalu menjadi merasa aman dalam mengajar dengan menggunakan alat dan perlengkapan yang telah disiapkan, hal ini juga yang menyebabkan guru dapat mengembangkan proses belajar mengajar dengan baik untuk meningkatkan kinerjanya. Intinya guru MAN merasa aman dalam menggunakan alat dan perlengkapan mengajar untuk meningkatkan kinerjanya sebagai seorang guru.

Ketiga, indikator interaksi sosial dari motivasi yang dimiliki guru menunjukkan pengaruh positif dan signifikan terhadap kinerjanya. Hal ini terjadi dalam aktivitas organisasi terjalin komunikasi vertikal dengan pimpinan, maupun horizontal dengan sejawat, interaksi sosial yang harmonis diantara warga madrasah menyebabkan peningkatan kinerja para guru untuk berkomunikasi dan bekerja sama dalam mengembang tugas pokok dan fungsi sebagai pendidik dan pengajar dalam melakukan proses belajar mengajar dengan baik. Akibat interaksi sosial yang harmonis, maka guru termotivasi dalam mengajar mengalami peningkatan yang menyebabkan motivasi kerja menjadi positif, dan hal ini menjadi signifikan dalam memberikan pengaruh terhadap kinerja guru. Artinya motivasi kerja yang meningkat akan memberikan pengaruh positif dan signifikan dalam meningkatkan kinerja guru di MAN.

Keempat, indikator penghargaan dari motivasi guru yang terjadi di MAN saat ini, guru yang telah menjalankan pekerjaan dengan baik, maka hasil kerja yang telah dilakukan mendapatkan pengakuan atau penghargaan atas apa yang telah dilakukan, sehingga guru merasa termotivasi dengan pekerjaannya karena hasil kerjanya diakui dan dihargai. Inilah salah satu faktor yang meningkatkan kinerja guru dalam mengembangkan proses belajar mengajar di madrasah. Intinya guru yang mendapatkan pengakuan dan penghargaan atas pekerjaan yang dilakukan menyebabkan guru dapat termotivasi untuk meningkatkan kinerjanya, inilah yang menyebabkan motivasi berpengaruh positif dan signifikan terhadap kinerja guru.

Kelima, indikator aktualisasi diri dari motivasi guru selama ini telah mendapatkan perhatian dan peluang bagi guru MAN untuk menunjukkan aktualisasi diri dalam meningkatkan kinerjanya. Aktualisasi diri guru yang diperhatikan dan dipertimbangkan mempunyai dampak motivasi pada guru untuk meningkatkan kinerjanya. Wujud aktualisasi diri bagi guru adalah mendapatkan peluang atau perhatian atas kreativitas, eksistensi dan ekspresi kerja yang dilakukan untuk dipenuhi dalam meningkatkan kinerjanya. Seperti guru menginginkan mendapatkan peluang untuk mengikuti berbagai kegiatan seminar-seminar, lokakarya atau penataran yang dapat meningkatkan aktualisasi dirinya dengan mendapatkan biaya dari madrasah untuk mengikuti kegiatan atau program tersebut, sehingga kegiatan tersebut dapat meningkatkan dan menunjang aktivitas karir profesional guru dalam meningkatkan kinerjanya. Intinya, jika guru mendapatkan perhatian atau peluang untuk mengembangkan aktualisasi diri dalam berkarir di bidang pengembangan pendidikan dan pengajaran, maka motivasi kerja guru semakin meningkat yang menyebabkan berpengaruh positif dan signifikan terhadap kinerjanya.

Berdasarkan uraian tersebut dapat disimpulkan bahwa motivasi kerja yang dirasakan oleh guru MAN saat ini telah terpenuhi tingkat kebutuhan psikologis yang layak, rasa aman atas pekerjaan, interaksi sosial yang harmonis dalam berkomunikasi yang terjadi di madrasah, pemberian penghargaan atas prestasi kerja yang diberikan dan peluang untuk mengaktualisasikan diri dalam berbagai kreativitas mengajar. Inilah yang menjadikan motivasi kerja guru positif dan signifikan terhadap peningkatan kinerjanya dalam melakukan proses belajar mengajar sesuai dengan kemampuan yang diharapkan yakni; membuat perencanaan dan persiapan, penguasaan materi, metode mengajar yang berkualitas, pemberian tugas kepada siswa, mampu mengelola siswa secara baik dan pemberian penilaian serta evaluasi atas aktivitas belajar yang dilakukan guru.

Motivasi kerja guru diharapkan terus meningkat dan memberikan pengaruh positif dan signifikan terhadap kinerja guru dengan terus memahami dan memenuhi tuntutan motivasi kebutuhan yang diinginkan oleh guru sebagai manusia biasa yang bekerja untuk memenuhi kebutuhannya sesuai dengan peningkatan kinerja yang dihasilkan. Ini menjadi penting dalam konsep manajemen pendidikan Islam sebagaimana ditunjukkan dalam Al-Quran dan Hadits Nabi Muhammad SAW. 
Pandangan manajemen pendidikan Islam sangat memperhatikan pentingnya pemenuhan motivasi kerja, yang terdapat dalam Q.S. Asy-syarh ( 94 : 7 dan 8),

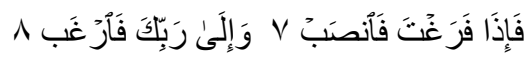

Terjemahnya:

Maka apabila kamu telah selesai (dari sesuatu urusan), kerjakanlah dengan sungguh-sungguh (urusan) yang lain. dan hanya kepada Tuhanmulah hendaknya kamu berharap.

Ayat ini memerintahkan kepada manusia untuk senantiasa memotivasi diri di dalam melakukan pekerjaan, sehingga setiap selesai melakukan suatu pekerjaan atau urusan, maka kerjakanlah dengan sungguh-sungguh urusan lainnya dengan mengharap semoga Allah memenuhi kebutuhan yang diinginkan manusia. Artinya, bagi seorang guru apabila motivasi kerja yang dirasakan menurun atau rendah, seharusnya senantiasa mengambil inisiatif untuk memotivasi diri dengan terus bekerja untuk memenuhi tuntutan kebutuhannya, dari satu pekerjaan ke pekerjaan yang lainnya yang menyebabkan kinerja meningkat. Ayat ini secara tegas menjadi pertimbangan perlunya memperbaiki motivasi kerja yang rendah dengan terus bekerja dari satu urusan dengan urusan lainnya untuk meningkatkan kinerjanya.

Selain itu, hadits yang relevan dengan perlunya memperbaiki motivasi kerja untuk meningkatkan kinerja guru yang lebih baik, sesuai Hadits riwayat Ad Dailami, "sesungguhnya Allah senang melihat hamba-Nya yang bersusah payah dalam mencari rezeki yang halal". Hadits ini mengingatkan bahwa manusia seharusnya selalu termotivasi untuk bekerja dengan sungguh-sungguh atau bersusah payah di dalam mencari rezeki yang halal. Inilah pentingnya ada motivasi kerja dalam diri setiap manusia seperti seorang guru harus terus memiliki motivasi untuk mengajar dengan penuh kesungguhan dalam meningkatkan kinerjanya.

\section{Penutup}

\subsection{Kesimpulan}

Berdasarkan analisis hasil dan pembahasan penelitian tentang Pengaruh Manajemen Kepemimpinan Kepala Sekolah dan Motivasi terhadap Kinerja Guru (Studi pada Madrasah Aliyah Negeri 1 di Kota Makassar), maka dapat disimpulkan sebagai berikut:

a. Kepemimpinan kepala madrasah secara langsung berpengaruh positif dan signifikan terhadap kinerja guru MAN 1 Kota Makassar, sehingga kepemimpinan kepala madrasah mempunyai andil dan peran yang sangat penting dalam mempengaruhi dan berkontribusi terhadap kinerja guru MAN 1 Kota Makassar.

b. Motivasi secara langsung berpengaruh positif dan signifikan terhadap kinerja guru MAN 1 Kota Makasar, hal ini merupakan salah satu pemenuhan terhadap motivasi kebutuhan yang menunjang bagi pencapaian kinerja guru dalam proses belajar mengajar di MAN 1 Kota Makassar.

\subsection{Saran}

Berdasarkan analisis dari hasil pembahasan dalam penelitian ini, maka disarankan:

a. Kepemimpinan kepala madrasah saat ini sudah berorientasi pada kinerja guru, sehingga perlu untuk dipertahankan di MAN 1 Kota Makassar, dengan meningkatkan dan memberikan pelatihan kepemimpinan yang Islami kepada kepala madrasah dengan salah satu konsep yang telah dicontohkan oleh Rasulullah SAW yakni pemimpin itu harus memiliki sifat Shiddiq, Tablig, Amanah dan Fathanah atau dikenal dengan konsep STAF.

b. Motivasi guru sudah sesuai dengan tuntutan kebutuhan bagi guru MAN 1 Kota Makassar yang memberikan kontribusi terhadap peningkatan kinerja guru dalam mengajar di MAN 1 Kota Makassar. 


\section{DAFTAR PUSTAKA}

Al-Qur'an dan terjemahnya, Departemen Agama Republik Indonesia.

Aqib, Zainal, Menjadi Guru ProfesionalBerstandar Nasional, Bandung: Yrama Widya, 2019.

Danim, Sudarman. 2010. Kepemimpinan Pendidikan. Bandung: Alfabeta.

Danim, Sudarman dan Suparno. 2012. Menjadi Pemimpin Besar, Visioner Berkarakter. Bandung: Alfabeta.

Departemen Pendidikan Nasional RI. Undang-Undang Republik Indonesia Nomor 20 Tahun 2003, Tentang Sistem Pendidikan Nasional. Jakarta: Depdiknas RI.

Marno, T. S, Manajemen dan kepemimpinan Pendidikan Islam . Bandung: PT. Refika Aditama, 2008.

Muliono, Pengaruh Kompetensi, Motivasi dan Tipe Kepemimpinan terhadap Kepuasan Kerja dan Kinerja Pengawas SMA/SMK di Provinsi Sulawesi Selatan, Makassar: 2017.

Muhaimin, et al, Manajemen Pendidikan Islam "Aplikasinya dalam Penyusunan Rencana Pengembangan Sekolah/Madrasah, cet. 2; Jakarta ; Kencana, 2010.

Nata, Abuddin, Manajemen Pendidikan: Mengatasi Kelemahan Pendidikan Islam di Indonesia. cet.5; Jakarta: Kencana Prenada Media Group, 2012.

Paskalis, dkk, Jurnal Administrasi Pendidikan; Kepemimpinan Kepala Sekolah dalam Menajemen Berbasis Sekolah, FKIP Universitas Tanjungpura, Pontinak.

Ramayulis, Ilmu Pendidikan Islam. Jakarta : Kalam Mulia, 2010.

Saefullah, Manajemen Pendidikan Islam, cet.3; Bandung: CV. Pustaka Setia, 2019

Usman, Husaini, Total Quality Management. Penerbit Bumi Aksara, Jakarta, 2006

Utomo, Sugeng, Jurnal Manajemen dan Kepemimpinan Kepala Sekolah yang Efektif, FKIP Universitas Wisnuwardhana, Malang.

Wahjosumidjo, Kepemimpinan dan Motivasi. Cet. 3; Jakarta: Ghalia Indonesia, 1987.

Zainal, Veithzal Rivai, Manajemen Sumber Daya Manusia untuk Perusahaan dari Teori ke Praktek. Cet 1; Jakarta: Raja Grafindo Persada, 2006. 